\title{
Discussion on Establishment of Local Tax System from the Perspective of Business Tax Transformation to Value-added Tax
}

\author{
Xiaoyan Shao
}

Aien International Institute, Dalian Jiaotong University, Dalian, 116021, China

\begin{abstract}
Keywords: business tax transformation to value-added tax, local tax system, business tax, value-added tax
\end{abstract}

\begin{abstract}
The plan of business tax transformation to value-added tax was proposed jointly by the Ministry of Finance and the State Administration of Taxation in October, 2011. On August 1, 2013, "the plan" was implemented all over the country. This makes us to reflect on operating layout of the original local tax system. However, the establishment of local tax system under the background of "business tax transformation to value-added tax" has more topics deserving our in-depth research. For the perspective of "business tax transformation to value-added tax", the author discusses the establishment of local tax system, analyzes relevant issues existing in current works, and thus proposes countermeasures for improvement.
\end{abstract}

\section{Introduction}

Based on the consideration of China's current market economic conditions, to establish and develop local tax system is one of important expressions for handling with property and right distribution between the central government and the local government. For better satisfaction with development requirements of harmonious socialist society, higher requirements are proposed for effective ways used to establish the local tax system. According to the author, therefore, the emphasis of this paper lies on effective approaches used to grasp the opportunities of "business tax transformation to value-added tax" and thus to comprehensively establish rational and standardized local tax system in China. Based on the current research background, the author thinks that an in-depth research on the establishment and scientific and standardized local tax system is beneficial to promote stable and harmonious development of local economy. Therefore, we should pay enough attention to the establishment of such system.

\section{Significance of Local Tax System}

Since the reform of the system of tax distribution in 1994, basic framework of local tax system is smoothly established. However, considerable places needing improvement still exist. At the same time, this constitutes important contents to be discussed in this paper. According to the author, we need to have a sufficient understanding of the significance of local tax system before the research on relevant issues about the establishment of local tax system. This understanding is beneficial for us to accurately recognize the development orientation of the current local tax system.

(I) Influence on central and local fiscal relations

Certain differences exist in the hierarchy of functions between the central government and the local government, which constitutes the bases for fiscal decentralization of the governments at the two levels. The central government decides to implement the long-term unified policy, while this policy is inconsistent with social development needs of the current China. In China, there are relatively great gaps between the rich and the poor. Moreover, great differences are found between different regions with respect to condition and direction of political and economic development. Not enough importance is attached to differences between different regions. Therefore, it is very difficult to realize effective and fair distribution of public products and satisfy different social demands. However, the local government can properly remedy this disadvantage as it has a 
relatively sufficient understanding of requirements of local social and economic development and actual needs of local residents. In the author's opinion, the central government can divide some property rights and office authority to the local government, letting the local government to realize authority and carry out the hierarchical government system. Hierarchical finance is corresponding to hierarchical government. To carry out fiscal decentralization between central and local governments and provide enough funds for the realization of local government' functions can not only drive the growth of local and regional economy but also contribute a lot to economic development of the whole country. Therefore, local tax system inevitably exists under this system of hierarchical government and hierarchical finance.

(II) Promote the growth of local government revenue and maintain revenue and expenditure in balance

Viewed from development conditions in recent years, the phenomenon of uptight revenue is found at some local governments. However, imbalance between financial revenue and expenditure also constitutes the development bottleneck of most local governments in China. For settlement of fiscal difficulties of local governments, however, local governments usually remedy financial deficit by means of debt financing. This pattern causes large-scale local government debts and debt ratios exceeding standard. The debt repayment pressure faced local governments can not be neglected. Thus, it can be found that sufficient importance should be attached to fiscal difficulties of local governments. Moreover, it is of great significance to establish a stable and standardized local tax system and achieved balanced financial revenue and expenditure of local governments.

(III) Conform to needs of local governments to guide economic development and adjust income distribution

On the one hand, great differences are found between different regions in economic development. Moreover, comparatively obvious imbalance is also found in the development of market economy. Therefore, unified tax rights fail to comply with the requirements of different regions for economic development. Based on the consideration of the basis for unified central tax rights, the author thinks that to establish local tax system, we should sufficiently combine actual development conditions of local society and economy, implement rational distribution of market resources, and properly achieve justice and high efficiency of social and economic development.

On the other hand, the government plays an indispensable role in guiding social progress and normal development of local economy. The development of local economy can not be separated from fiscal revenue of the local government, while fiscal revenue undoubtedly constitutes fund guarantee of the development of local economy. Enough tax revenue can increase control rights and initiatives of local economic development, so as to strengthen scientific allocation of public products, correctly guide healthy development of market economy, realize rational distribution of public resources in the entire society, comply with development needs of socialist market economy, and allow local government to give a full expression to its superiority in promote the development of local economy.

\section{New Challenges for Development of Local Tax System under "Business Tax Transformation to Value-added Tax"}

The implementation of "business tax transformation to value-added tax" is an important measure for structural tax reduction in the period of the $12^{\text {th }}$ Five-Year Plan. In terms of its process, it is circuitous and unpredictable. Issues and challenges involved in the transformation are relatively complicated as well:

(I) Guarantee local government revenue and determine new main tax categories

Before the implementation of "business tax transformation to value-added tax", main income of local governments is from business tax. Business tax plays an irreplaceable role in raising local government revenue. With data in 2011 as an example, business tax accounts for $15.25 \%$ of tax revenue of the whole country. After the implementation of "business tax transformation to value-added tax", it undoubtedly shakes the position of main tax category of business tax in local 
tax system, leading to great reduction to local tax revenue, and driving differences between the central government and local governments. This inevitably requires to reestablishing new main tax category of local tax, so as to stabilize and guarantee tax revenue of local governments. However, it is not a simple process for the cultivation of new main tax categories.

(II) The reform of fiscal relations between the central government and local governments

The reform of "business tax transformation to value-added tax" expands the revenue scale of value-added tax as the first biggest tax category in China's tax system. However, sacrifice of business tax as main revenue of local tax is taken as a premise. Rights of value-added tax revenue allow both the central government and local governments to use in combination. For the issue of increased revenue, hierarchy between the central government and local governments should also be considered. The game of value-added tax hierarchical proportion between the central and local governments arouses the adjustment to financial relations between the central government and local governments. While establishing local tax system, we should take the following issues into full account: whether local tax revenue can be remedied only by the adjustment to value-added tax hierarchical proportion; or scientific approaches should be utilized to strengthen the transformation amounts of the central governments for local governments.

(III) The issue of existence exist in local tax institutions.

Due to the implementation of "business tax transformation to value-added tax", business tax originally levied by local tax institutions is now levied by state tax instituti0ons. Apparently, this is easy to cause imbalanced workload distribution between local and state tax institutions in business workload. Workloads of local tax institutions are remarkably decreased, while state tax institutions will shoulder more new works. Thus, the issue of dismiss or return will be caused among local tax institutions and relevant workers. From a short-term perspective, the management of local and state tax institutions with a combinative pattern can control levy costs to some extent and improve the efficiency of current tax works. From a long-term perspective, however, the necessity of local tax institutions' existence will be increased once new main tax categories are cultivated in local tax system.

\section{Countermeasures for Establishment of Local Tax System under "Business Tax Transformation to Value-added Tax"}

We can see from above analysis that the reform of "business tax transformation to value-added tax" brings about new opportunities and challenges to the establishment of local tax system. Based on relevant data, the author combines his cognition of this topic, and proposes countermeasures for the establishment of local tax system under "business tax transformation to value-added tax":

(I) Perfect the establishment of local tax system

We should perfect the establishment of tax law system and give full ply to the supervision significance of this system in the process of tax administration behaviors. This not only complies with development needs of the reform of "business tax transformation to value-added tax" but also functions as an inevitable requirement for the establishment of the current local tax system in China. Viewed from the current background of "business tax transformation to value-added tax", the issue of low legislative level certainly exists in China's tax laws and regulations. Blank points and blind points of tax policies are closely associated with incomplete tax law system of China, which is not beneficial to smooth development of the reform.

Firstly, standardized laws and regulations should be utilized for the improvement of various provisional conditions involved in the current system. Besides, various tax matters should be determined through legislative forms, for instance, value-added tax and estate tax. Moreover, we should enhance legal restraints of laws and act in strict accordance with the basic state policy of "rule by law". As suggested by the author, relevant personnel should also give appropriate coaching and training for professional ethics and works of tax collection and management and improve their work efficiency in the perfection process of legislation.

Secondly, proper limits of authority for revenue and legislation should be given to upgraded 
governments. The central government can transfer some taxation and legislative authorities to local governments, so as to guarantee revenue collection of local governments according to local circumstances and to implement supports of governmental functions and financial funds. This also gives an expression to the basis for the establishment of local tax system of China. Therefore, it is essential to strengthen the establishment of laws and regulations in the division and matching process of taxation rights. China has a unique political and economic development history. Moreover, great differences are seen in development level between different regions. As a result, different regions have different demands for public products. Therefore, uniformly prepared tax laws adopted by the central government fail to be completely applicable to economic and social development of different regions in the whole country. Apparently, it is quite necessary to give certain taxation and legislative rights to provincial governments. Furthermore, different regions should combine their development conditions, control the current tax sources within a reasonable scope, set up tax categories adaptive to local development, and fully redeploy the initiative of the development of local economy.

(II) Make scientific adjustments to property rights of the central and local governments

Viewed from actual conditions of China, local tax institutions should be responsible for taxation and management of business tax and the national tax bureau for taxation of value-added tax. After the implementation of the policy of "business tax transformation to value-added tax", some enterprises or self-employment ventures originally paying business tax transfer to pay value-added tax. In this process, it inevitably will involve the issue of tax revenue distribution between the central and local governments. In the author' opinion, therefore, importance should be attached to coordinated relations between the central and local governments with respect to tax revenue distribution. Moreover, reasonable adjustments should be made to the distribution of property rights between the governments at both levels. This is also resulted from the consideration of local governments' tax income.

At first, proper adjustments should be made to the distribution proportion of value-added tax revenue between the central and local governments after the implementation of "business tax transformation to value-added tax". Secondly, local governments should be allowed to increase the proportion of transfer payment and make reasonable adjustments to tax rate by combining development conditions of local economy. Some increased incomes from adjustment should be distributed to local governments. At last, cooperation between different organs and different departments should be strengthened, especially after the completion of pilot projects of "business tax transformation to value-added tax". More tax collection and management works should be completed by coordination between local tax organs and national tax organs. The current administrative and judicial efficiency can be radically improved only by perfecting cooperative relations between both organs.

(III) Rationally expand the scale of local taxation

In the reform process of local tax system, each country has to consider reasonable determination of the scale of local tax revenue. Appropriate local tax revenue and system is also established according to the principle of matched office authority and financial resources. Two points should be noticed while expanding the scale of local tax revenue: the first one is the increase of local tax revenue's proportion in national tax revenues. The second one is the perfection of China's current local tax system and collection \& management mechanism.

Appropriate changes should be made to the traditional system in which several taxes are collected under uniform amount and rate. Over the years, normal growth of China's tax revenue is already influenced by the collection system applied into resource tax, estate tax and other tax categories. At this moment, local governments should change lagged concepts and take different measures for different tax categories, for instance, to set up inheritance tax, levy tax for donation and similar matters, establish all-round local tax system, or enhance fiscal construction of local governments. 


\section{Conclusion}

From the perspective of "business tax transformation to value-added tax", an in-depth research is made in this paper on the establishment of local tax system. The discussion emphasis is laid on effective solutions to finance distribution between the central and local governments, so as to establish a rational incentive and constraint mechanism, guarantee sound and sustainable development of local governments, and maintain stable economic development. This paper is of certain guiding significance academically and practically.

\section{Acknowledgments}

This paper is the topic of educational science of Liaoning Province in the $12^{\text {th }}$ Five-Year Plan in 2014: Research on Fiscal Policy for Promotion of Higher Education Development (JG14DB078).

\section{References}

Cui Zhikun, Wang Zhenyu and Chang Binbin, Reflection on Perfection of Local Tax System under the Background of "Business Tax Transformation to Value-added Tax" [J], Economic Review, 2014 (01);

Guo Yuemei, Discussion on Perfection of Local Tax System under the Background of "Business Tax Transformation to Value-added Tax” [J], Public Finance Research, 2014 (06);

Liu Jianhui, An Ran and Zhou Zhibo, Research on Establishment of China's Local Tax System under Inclusive Development Background [J], Macroeconomic Research, 2014 (06);

Gao Peiyong, Functional Orientation and Previous History of "Business Tax Transformation to Value-added Tax” [J], Taxation Research, 2013 (07);

Qiu Jin, Research on Functional Orientation of Local Taxation Bureaus - with Local Tax of Hubei Province after “Business Tax Transformation to Value-added Tax" as an Example [D], Shanghai: Central China Normal University, 2013. 